The Interaction Effect of Auditor

\title{
Dr. Mawaheb Abdel-Aziz
} Ismail

Accounting Lecturer

Department of Accounting

Alexandria University

Industry Specialization and Ownership Concentration on Investment Efficiency: Evidence from Egyptian Stock

Exchange

\section{Abstract}

The paper examines the interaction effect of auditor industry specialization and ownership concentration on investment efficiency for a sample of firms listed on the Egyptian Stock Exchange during the period from 2011 through 2018.

I predict that specialized auditors and ownership concentration have positive impact on investment efficiency. It's further predicted that specialized auditors moderate the relation between ownership concentration and investment efficiency. Results reveal that specialized auditors enhance investment efficiency, while ownership concentration adversely affects investment efficiency. Results fail to support any interaction effect between auditor industry specialization and ownership concentration.

Keywords: Investment efficiency, corporate governance, audit industry specialization, ownership concentration.

E.mail: mawaheb.ismail@gmail.com 
التأثير التفاعلي للتخصص الصناعي لمراقب الحسابات وتركز الملكية على كفاءة الاستثمار : دراسة تطبيقية على الثركات المقيدة بالبورصة المصرية

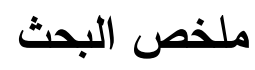

يتاول البحث دراسة التأثير التفاعلي لتخصص مراقب الحسابات في الصناعة وتركز الملكية على

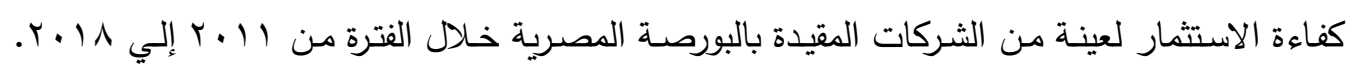
افترضت الدراسة وجود علاقة موجبة بين كل من التخصص الصناعي وتركز الملكية على كفاءة الاستثمار . كما تتبأت بوجود تأثير تفاعلي لكراقب الحسابات المتخصص على العلاقة بين تركز الملكية وكفاءة الاستثمار. وقد توصل البحث إلى قبول فرض وجود علاقة جوهرية موجبة بين التخصص الصناعي لمراقب الحسابات وكفاءة الاستثمار، ورفض فرضية وجود علاقة جوهرية موجبة بين تركز الملكية و كفاءة الاستثمار . كما استبعدت النتائج وجود تأثير تناعلي لمراقب الحسابات المتخصص على العلاقة بين تركز الملكية وكفاءة الاستثار ـ وقد أكدت الاختبارات الاضافية و تحليل الحساسية النتائج السابقة. الكلمـات المفتاحية: كفاءة الاستثمار، حوكمة الثركات، التخصص الصناعي لمراقب الحسابات، تركز الملكية. 


\section{1- INTRODUCTION}

Investment plays an important role in motivating growth through increase in productivity levels. Investment in financial markets helps boosting aggregate demand, effective in driving economic growth rate. Investment, whether local or foreign, enhances technology, creates employment, explores hidden markets, introduces management and organizational skills, and improves labor and capital quality through competition. Therefore, factors affecting investment efficiency are important issue to be addressed.

Financial markets' growth is tightly bounded to investment efficiency, which reflects how well corporations are directed and managed. For this main reason, corporate governance was introduced to align as possible the interests of individuals, corporations, and society. According to OECD (1999), corporate governance concerns with the relationship between management, BOD, shareholders and other stakeholders. Corporate governance helps ensuring that an adequate and appropriate structure of controls operates within a company to prevent any single individual of having too power or influence. Moreover, corporate governance requires mechanisms ensuring both transparency and accountability, mostly required by investors regarding company's management and performance.

During the last two decades, and for the very reason of enhancing transparency and maintaining credibility in Egyptian Stock Market, several regulatory mechanisms have been developed, one of which is the issuance of corporate governance code. The Egyptian Code of Corporate Governance was introduced in October 2005 by the Egyptian Institute of Directors. This code was revised and adjusted in 2011 by the Egyptian Financial Supervisory Authority, created by Law 10/2009. The last reform for the code was on August 2016, through the cooperation of both the Egyptian Institute of Directors and the Egyptian Financial Supervisory Authority. It is expected that such regulation, among others, would improve performance of listed companies and enhance investment efficiency. 
This study addresses two corporate governance mechanisms that affect investment efficiency; these are auditor industry specialization (as a driver of perceived audit quality), and ownership concentration. External audit is an external governance mechanism that reviews and evaluates client internal controls and audits their financial reports in order to detect and document material misstatements. Being an integral dimension of corporate governance, a bulk of studies (e.g., Balsam et al. 2003, Krishnan 2003, Dunn and Mayhew 2004, Li et al. 2010, Bae and Choi 2012, Lenard and Yu 2012, Bae et al. 2017 and others) has attempted to link audit proxies to aspects such as firm performance, earnings quality, value relevance, disclosure quality, cost of debt, and investment efficiency.

Literature has identified many indicators for audit quality, including audit size (Becker et al. 1998, Francis et al. 1999, Krishnan 2003, Chia et al. 2007, Lin and Hwang 2010, Zgarni et al. 2012), audit tenure (Myers et al. 2003, Ghosh and Moon 2005, Crabtree et al. 2006, Gavious 2007, and Gul et al 2010), and auditor independence (Beeler and Hunton 2002, Mayhew and Wilkins 2003, Solomon et al. 2005, Brown et al. 2008, and Lin and Hwang 2010).

Auditors' industry specialization has been introduced as a sophisticated measure of audit quality. Solomon et al. (1999) argue that industry specialist auditors have a deeper knowledge and greater experience which enable them to make more accurate audit judgments and conduct higher quality audit work. Thus, there are several potential benefits from hiring industry specialist auditor; cited in ability to identify misstatements more effectively, correct and report identified misstatements to maintain their reputation, and assist clients in developing and disseminating enhanced disclosure (Dunn and Mayhew 2004). A sizable body of research analyzed and supported the positive impact of auditor industry specialization on audit quality and earnings quality (e.g., Krishnan 2003, Francis and Wang 2005, Taylor 2000, Owhoso et al. 2002, and others). Building on this established link, the study hypothesizes that specialist auditors enhance investment efficiency.

Ownership concentration has been perceived as one important dimension of firm's internal corporate governance mechanisms. Prior studies examining the 
impact of ownership concentration based their analysis on agency theory, firstly introduced by Jensen and Meckling (1976). Agency theory demonstrates a principal-agent relationship, where principals (owners) delegate work and day-today decisions to agents (managers). This separation between ownership and control creates a conflict of interest between owners as wealth maximizers and managers as self-interest seekers. It is highly argued that auditors and independent directors, as the key firm monitoring mechanisms, can restrain such agency conflict (Benkraiem 2009).

The impact of ownership concentration on firm's performance has been the subject of many studies (such as Azofra et al. 2003, Wahba 2014, Al-Rassas and Kamardin 2016, Chen et al. 2017, and others). The results of these studies illustrate that the effect of ownership concentration, whether positive or negative, is a function of multiple factors; such as type of ownership (managerial, institutional, state-holding, block-holding, or foreign ownership), stock market system (outsider, or insider), and level of legal protection provided by the country.

During the adoption and reinforcement of corporate governance practices, the Middle East countries, including Egypt, have experienced certain problems, where the economies of these countries have particular characteristics. These characteristics are cited in; high level of ownership concentration, excess government intervention, weakness of legal systems and enforcement mechanisms, and less developed legal structures and institutions. Egypt, as an emerging country, has a relatively small undeveloped capital market lacking discipline and control. In such context of weak enforcement mechanisms, ownership concentration can serve as an alternative internal governance tool in mitigating agency problems (Shleifer and Vishny 1997, and Burkat and Panunzi 2001). Based on this theoretical argument, the paper predicts that ownership concentration improves investment efficiency.

Corporate governance codes incorporate various dimensions; disclosure and transparency, structure of board of directors, shareholders' rights and investor relations, and ownership and control structure. Prior research (Brunninge et al. 2007, Florackis 2008, Sulong and Nor 2010, Wahba 2014, and Khanqah 2015) 
lends credence to the idea that an interaction relationship may arise between such mechanisms. This study predicts that auditor industry specialization moderates the relationship between ownership concentration and investment efficiency.

This paper aims at investigating the link between corporate governance mechanisms and investment efficiency in the Egyptian context. The research importance stems from the current critical period through which the Egyptian economy passes, where investment efficiency is the main participant in growth and development. The paper adds to the literature examining the effect of different corporate governance mechanisms on firm performance measures, namely, investment efficiency. The study employs a sample of 592 firm-year observations from listed Egyptian companies over the period from 2011 to 2018.

Empirical results reveal that auditor industry specialization enhances investment efficiency, especially for underinvesting firms. Moreover, ownership concentration negatively affects investment efficiency. Also, specialized auditors appear incapable of limiting the adverse effect of ownership concentration on investment efficiency. The results are robust to sensitivity checks using different measurement indicators.

The paper proceeds as follows. In section II, motivation, as well as, hypotheses is provided. Sample and research methodology are described in section III. Section IV presents empirical results. The study concludes with a brief summary in section $\mathrm{V}$.

\section{2- LITERATURE REVIEW AND HYPOTHESES DEVELOPMENT}

\section{2-1 Auditor Industry Specialization}

The ultimate goal of corporate governance is to produce reliable financial reports, upon which sound investment decisions can be taken so that sufficient returns are produced (Bin-Zulkafli et al. 2007). High quality audit is perceived as important monitoring mechanism to safeguard shareholders' interests.

The association between auditor industry specialization and audit quality is perceived to be almost a settled issue. The reason is that numerous studies (such 
as Simunic and Stein 1987, Solomon et al. 1999, Taylor 2000, Hammersley 2006, and others) examined such a linkage and proved it positive across different contexts, industries, and samples. The theoretical perceptive for the fact that industry specialist auditors conduct higher audit work is that; more expertise auditors have higher market share, which enable them to develop more industryspecific knowledge necessary to perform higher quality services compared to low market share audit firms (Mayhew and Wilkins 2003).

Prior studies used earnings quality indicators to denote audit quality, where audit service is not objectively measurable and audit process is not directly observable, as argued by Balsam et al. (2003). For instance, some studies (e.g., Krishnan 2003, Balsam et al. 2003, and Dunn and Mayhew 2004) examine the relationship between auditor industry specialization and absolute discretionary accruals, earnings response coefficient, and disclosure quality. They reached that industry specialists have lower discretionary accruals, higher earnings response coefficients, improved earnings quality, and higher analysts' rankings of disclosure quality.

Earlier research explored other aspects related to auditor industry specialization; such as specialists' fundamental outperformance in error characteristics and detection methods across industries (Maletta and Wright 1996). Also, Dopuch and Simunic (1982) pointed that specialized auditors are more likely to invest more in staff recruitment and training, information and audit technologies than non-specialist auditors. In addition, specialized auditors exhibit greater compliance with auditing standards and are less subject to SEC enforcement actions (O'Keefe et al. 1994, and Carcello and Nagy 2004). Moreover, when comparing specialists and non-specialists in conducting analytical procedures tasks within manufacturing industry, Green (2008) found that specialized auditors implemented more focused and efficient information search as they were able to detect the correct causes of problems during the task. 


\section{2-2 Auditor Industry Specialization and Investment Efficiency}

Investment efficiency is a function of the risk, return and total cost of investment management, subject to the constraints within which investors must operate. These constraints include financial elements and non-financial elements such as an investor's time available to manage the investment arrangements, accountability as a fiduciary, or legislative requirements. Investment efficiency should therefore be regarded as a combination of financial efficiency and non-financial efficiency (Hodgson et al. 2000). Financial efficiency includes factors such as free cash flow, growth rate, earnings, and value of total assets. Whereas, non-financial efficiency includes factors such as quality of financial reporting, audit quality, management team skills, and shareholders power.

Prior literature shows that high quality financial reporting and corporate governance mechanisms can help prevent or mitigate firm's suboptimal investments by disciplining managers' behaviors and reducing cost of capital (Biddle et al. 2009, Cheng et al. 2013, and García Lara et al. 2010). Richardson (2006) finds that the over-investment of free cash flows can be mitigated by certain governance structures such as the presence of activist shareholders and the adoption of anti-takeover provisions.

As previously illustrated, specialized auditors have the potential in restricting managerial opportunistic behavior, this follows that they are expected to improve investment efficiency. Such expectation can be justified in several ways. On the one hand, industry specialists most probably have a greater knowledge of industry accounting practices, and thus are better able to identify and deter aggressive practices. On the other hand, and as suggested by Chen et al. (2011), specialists have developed a reputation for industry expertise, and so they have an incentive to protect their reputation in order to earn audit fee premium for that expertise. Therefore, specialists protect their reputation by resisting client pressure for greater discretion and by imposing stricter standards on clients in order to minimize the risk of misleading reporting (Reichelt and Wang 2010). 
Results of earlier research corroborate a link between accounting quality and investment efficiency. Biddle and Hilary (2006) examine in what means accounting quality is related to investment efficiency both at firm and country levels using US and Japanese settings. Four accounting quality measures were employed; namely earnings aggressiveness, loss avoidance, earnings smoothing, and timeliness. Their results verify that accounting quality is positively associated with lower investment-cash flow sensitivity; denoting higher investment efficiency. In a follow-up study, Biddle et al. (2009) uncover that high financial reporting quality is associated with lower over-and-under investments, that is, lower deviations from predicted level of investment. The argument is that higher financial reporting reduces information asymmetry between firms and external capital providers through focusing on positive net present value projects.

Focusing on the inverse measure of earnings quality, earnings management, Kedia and Philippon (2009) emphasized that fraudulent accounting distorts investment decisions and impose more cost on shareholders. In the same line of thought, McNichols and Stubben (2008) argue that manipulated figures can mask the underlying trends in revenues and earnings growth. Thus, overstatements of revenues and earnings are likely to mislead the growth expectations of those unaware of the misstatement.

Based on the above analysis and building on the two facts that specialized auditors have the ability to direct and motivate their clients toward higher quality financial practices, and that higher financial reporting quality improves investment efficiency, then my first research hypothesis can be formulated as follows:

H1: Financial Reports of firms audited by specialized auditors would show higher levels of investment efficiency (or lower deviations from expected investment level).

\section{2-3 Ownership Concentration}

The second dimension of corporate governance discussed in this paper is the ownership concentration. Firm's ownership structure is considered to be of criti- 
cal importance to the effectiveness of oversight mechanisms employed to reduce fraudulent practices and enhance investment efficiency.

A bulk of empirical research has examined the impact of ownership structure on various aspects; such as firm performance, earnings quality, investment efficiency, value relevance, and financial distress (Bushee 1998 \& 2000, Koh 2003, Bergstresser and Philippon 2006, Wang and Deng 2006, Florackis et al. 2009, Huang 2010, Elsayed and Wahba 2014, and Shahwan 2015). Two viewpoints were introduced by literature. The first line of thought promotes for the positive impact of ownership concentration, as a monitoring mechanism. It is emphasized that if managers or insiders acquire a considerable portion of firm's shares, this would force them to bear the wealth consequences of their decisions, thus reducing agency conflicts and better align the interests of managers and shareholders. Additionally, outsiders who own a significant number of firm's shares (blockholders) would have more power and more incentive to monitor managers' actions and practices, and "voice" their concerns and objections as a result of their large voting rights (Persons 2006), and in turn, reduce the likelihood of earnings management. This argument has been proven valid by Azofra et al. (2003), Peasnell et al. (2005), Imam and Malik (2007), Laux and Laux (2009), where all reach that ownership concentration has a positive impact of firm performance, assessed using different proxies.

The second line of thought demonstrates that ownership concentration adversely affects firm performance and financial reports' quality; thereby prevent attaining corporate governance objectives. It is postulated that increasing managerial ownership in the firm would put managers in a position serving their own interests and exploit other minority shareholders (Shleifer and Vishney 1989, and Stulz 1990). Moreover, large block-holders can put pressure on managers to engage in income-increasing earnings management to report favorable financial performance (Zhong et al. 2007). A considerable number of studies provide empirical evidence consistent with this line of reasoning, for example, Claessens et al. (2000), Lasfer (2006), Wang (2006), Chen et al. (2017), and others. 
Institutional ownership creates bigger space for debate and disagreement concerning their impact on firm performance. There are two opposing argument; first, institutional investor concentration reduces the quality of accounting earnings. Second, institutional ownership concentration improves performance and constrain earnings manipulation. In fact this conceptual issue has attracted the attention of many empirical researchers (Koh 2003, Liu 2006, Ferreira 2007, Charitou et al. 2007, Cheng and Reitenga 2009, and others) . However, "Bushee" has been the earliest and the best known spokesperson for the role of institutional ownership in financial markets. Based on investment horizon, Bushee (1998 \& 2000) classified institutional investors into short-term and long-term institutional shareholders. Short-term or transient institutional investors focus mainly on current earnings rather than long term performance. Their monitoring role is limited; where they prefer to sell their shares if firm's results are not satisfactory, rather than monitoring or replacing inefficient management. It's believed that pressures for myopic inefficient investment behavior are created by those transient institutions. Long term institutional investors, who have the intention to hold shares over a long period, have a strong incentives to monitor managers and deter their fraudulent practices.

\section{2-4 Ownership Concentration and Firm Performance indica- tors, one of which is Investment Efficiency}

The mixed results of prior empirical research leave open the question of whether ownership concentration has a positive or negative impact on firm and market measures. Researchers used different contexts, employed various proxies, and reached different results. Azofra et al. (2003) employ sample of firms quoted in the Spanish capital market to examine the relation between ownership concentration and earnings quality, debt financing and investment. Empirical evidence explores that absolute value of discretionary accruals declines, and investment opportunity set rises with ownership concentration; consistent with large shareholders playing an active role in corporate governance. In Australia, Koh (2003) and Hus and Koh (2005) examine the effect of managerial ownership concentration on earning management. Findings verify that managerial owner- 
ship encourages managerial accruals discretion, thereby decreasing earnings informativeness.

In another context, Teshima and Shuto (2006) used a large sample of Japanese firms to examine the extent to which managerial ownership concentration affects earnings management. They reach that within intermediate levels of managersholding, such relation is significantly positive. For low and high levels of managerial ownership concentration, discretionary accruals are negatively affected by managers-holding. Imam and Malik (2006) provide evidence from Bangladesh Stock Market on the impact of ownership structure on firm indicators. Results confirm that foreign holding is positively and significantly related to firms' return indicators and Tobin's Q. In Malaysia, Al-Rassas and Kamardin (2016) reach that ownership concentration lower earnings quality, and that audit function moderates such effect.

For our context, Egypt has witnessed major changes in its political and economical environment during the past few decades. Egyptian business culture has experienced major developmental stages: Colonial Period, Central Planning, Slow Development, Moderate development, and Rapid Development (Hassab el Naby and Mosebach 2005). Until 1952 and starting from the British Colonialism, Egypt was a capitalistic country where the private sector was controlling $76 \%$ of the Egyptian investment. The revolution of 1952 shifted Egypt from a capitalist economy to socialist economy, and for three next decades, public sector's dominance increased dramatically (Carana 2002). In 1974, the government enacted the Foreign Investment Law aiming to encourage foreign investments in the form of joint ventures with domestic, foreign and Arab investors.

As a result of the huge deficits in the balance of payments, Egypt has involved in an Economic Reform Program in 1991 with the World Bank and the International Monetary Fund. The economic reform program incorporates major elements cited in lessening consumer subsidies, diminishing public sector, and increasing energy prices to realistic levels (Abd el Salam and Weetman 2003, Ragab and Omran 2006). The main aim was to shift the economy from a statedominated to a market-oriented economy. As a part of the Economic Reform 
Program, privatization necessitates the reactivation of the Egyptian Stock Market that has almost been absent during the period from 1957 to the late 1980s. The result is that the majority of firms listed on Egyptian Stock Exchange were privatized public sector companies.

The above analysis paves the way to elaborate my second research hypothesis. Building on the history and specific characteristics of Egyptian Stock Market, where legal systems and enforcement mechanisms are weak, legal structures and institutions are less developed, and capital market participants lack discipline and control, ownership concentration can serve as an alternative internal governance tool in mitigating agency problems and information asymmetry.

\section{Therefore, my second research hypothesis can be formulated as follows:}

H2: Financial Reports of firms with concentrated ownership would show higher levels of investment efficiency (or lower deviations from expected investment level).

\section{2-5 Interaction Effect of Auditor industry Specialization and Ownership Concentration on Investment Efficiency}

Prior corporate governance research indicates that an interaction relationship may arise among various governance mechanisms (e.g., Brunninge et al. 2007, Florackis 2008, Sulong and Nor 2010, and others).

A complementary relationship between auditor industry specialization and ownership concentration may exist as a result of interaction between powerful shareholders and external auditors. Active powerful shareholders, especially institutional investors sitting on the audit committee, have opportunities to regularly meet with external auditors to review audit process, firm's strategy and operational performance, internal control systems, performance of executive management, incompliance with corporate governance codes, and remuneration packages.

Additionally, a substitute relationship between auditor industry specialization and ownership concentration may arise. If block-holders become more influential over company management, they may pursue their own interests and exploit 
other small shareholders, external auditors' role must intervene to protect minority interests.

Therefore, my third research hypothesis can be formulated as follows:

H3: Auditor industry specialization moderates the relationship between ownership concentration and investment efficiency.

\section{3- RESEARCH DESIGN}

\section{3-1 Data and Sample Selection}

Initial study sample comprises 120 most active firms listed on the Egyptian Stock Market during the period 2011-2018. The study considers data from 2011, wherein Egyptian code of corporate governance was revised and adjusted by the Egyptian Financial Supervisory Authority. To obtain suitable homogeneous data, companies belonging to financial sector were excluded, also firms with uncompleted and/or missing data of study variables. As a consequence, final sample comprises 74 firms belonging to five sectors. Data collection was conducted through data stream and annual reports available on the website of "Mubasher Misr". Sample selection and distribution are presented in Table (1).

\section{Table (1): Sample Selection and Distribution}

\begin{tabular}{|c|c|c|c|}
\hline \multicolumn{4}{|l|}{ Panel A: Sample Selection } \\
\hline \multicolumn{3}{|l|}{ Initial Sample } & 120 \\
\hline \multicolumn{3}{|l|}{ Excluding: $\mathrm{Ba}$} & (25) \\
\hline \multicolumn{3}{|c|}{ Companies with uncompleted annual reports } & (13) \\
\hline \multicolumn{3}{|c|}{ Companies with missing data of study variables } & $(8)$ \\
\hline \multicolumn{3}{|l|}{ Final Sample } & 74 \\
\hline \multicolumn{4}{|c|}{ Panel B: Sample Distribution by Industry } \\
\hline Industry & Firms & Observations & $\%$ \\
\hline Construction \&Materials & 25 & 200 & 34 \\
\hline Chemicals \& Pharmaceuticals & 10 & 80 & 14 \\
\hline Industrial \& Basic Resources & 19 & 152 & 26 \\
\hline Leisure \& Entertainment & 13 & 104 & 17 \\
\hline Media \& Communications & 7 & 56 & 9 \\
\hline Total & 74 & 592 & 100 \\
\hline
\end{tabular}




\section{3-2 Measurement of Research Variables}

\section{3-2-1 Investment Efficiency}

Investment efficiency indicates the ability of the firm to get positive net values from all of its projects. Various measures are used to assess investment efficiency. For instance, Verdi (2006) has developed an empirical model to identify the investment efficiency of the business based on the factors like growth, leverage, cash, size, return, and age. Biddle et al (2009) perceives investment efficiency as covering the capital expenditure, and research and development, minus sales of property, plant and equipment, lagged values of total assets.

Following prior research (Biddle et al. 2009, Bae and Choi 2012, and Khanqah 2015), I interpret investment efficiency as firms undertaking projects with a positive net present value. This entails that under-and over-investment denotes investment inefficiency as recessing investment opportunities with positive net present value and investing in projects with negative net present value, respectively.

Since researchers are incapable of directly observing firm's investment opportunities and decisions, one more practical way is to define normal or expected investment level, and consider any deviations from such expected level as inefficient investment. Put it differently, a firm will be viewed as investing inefficiently if its actual investment level deviates from expected investment level. Both under-investment (negative deviations from expected investment level) and over-investment (positive deviations from expected investment level) are perceived as inefficient investments.

In order to identify investment expected level, I employ investment decision model adopted by Biddle et al. (2009) and Khanqah (2015), where investment is a function of growth opportunities measured by sales growth. Residuals of the model are used as proxy for deviations from expected investment, denoting investment inefficiency. 
Expected investment model is as follows:

\section{$\mathrm{Invt}_{\mathrm{i}, \mathrm{t}+1} / \mathrm{TA}_{\mathrm{i}, \mathrm{t}}=\beta_{0}+\beta_{1}$ Sales Growth $\mathrm{i}_{\mathrm{i}, \mathrm{t}} / \mathrm{TA}_{\mathrm{i}, \mathrm{t}-1}+\dot{\varepsilon}_{\mathrm{i}, \mathrm{t}+1}--------(1)$}

Where;

Invt $_{i, t+1} / \mathrm{TA}_{\mathrm{i}, \mathrm{t}}$ is the sum of new investment in property, plant and equipment less the sale of fixed assets for firm $i$ in year $(t+1)$, lagged by total assets for firm $i$ in year $t$.

Sales growth $\mathrm{i}_{i, t}$ is the annual sales revenue growth rate for firm $\mathrm{i}$ in year $\mathrm{t}$ [(current year sales - prior year sales) / prior year sales]

$\dot{\boldsymbol{\varepsilon}}_{\mathbf{i}, \mathbf{t + 1}}$ are the residuals of the model, denoting deviations from expected investment level.

Since both under-and over-investment are considered as investment inefficiency, the primary dependent variable is the absolute value of residuals. Taking into consideration that the relationship between independent variables (auditor industry specialization / ownership concentration) and firm's investment efficiency might not be symmetric around over-and under-investment, as an additional test, residuals will be split into over-investment (greater than or equal zero) and under-investment (less than zero) in order to investigate their relation with auditor industry specialization and ownership concentration.

\section{3-2-2 Auditor Industry Specialization}

Industry specialization is well accepted to be identified based on the market share of audit firm in a specific industry. While different measures are used in the literature to determine market share of audit firm, the most widely used measure is based on the client's total assets. This measure has been widely used by prior research (Balsam et al. 2003, Krishnan 2003, Dunn and Mayhew 2004, Lim and Tan 2009, and Bae and Choi 2012).

The model used to calculate audit firm market share based on relative total assets is as follows:

$\mathrm{MS}_{\mathrm{ik}}=\Sigma$ Assets $_{\mathrm{ijk}} / \Sigma \Sigma$ Assets $_{\mathrm{ijk}}-----(2)$ 
Where;

$\mathrm{MS}_{\mathrm{ik}}$ is the market share of audit firm $\mathrm{i}$ in industry $\mathrm{k}$.

$\Sigma$ Assets $_{\mathrm{ijk}}$ is total assets of client firm $\mathrm{j}$ in industry $\mathrm{k}$ audited by audit firm $\mathrm{i}$.

The paper will define an audit firm with largest market share as a specialized auditor.

It is noteworthy that client sales are also used to assess audit firm market share (e.g., Bae and Choi 2012 \& Sun and Liu 2013). The study will employ this measure in its sensitivity test. Moreover, market share based on either total assets or sales is a continuous measure of auditor industry specialization. Some studies use discrete proxies for specialization; where they perceive specialized auditor as having market share above a certain percentage, or exceeding the second largest auditor by a certain percentage (Mayhew and Wilkins 2003). That is, different studies employ different definitions for assessing auditor industry specialization.

\section{3-2-3 Ownership Concentration}

As previously discussed, ownership concentration can play a significant role in controlling agency problems. It is argued that the ability of shareholders to act as an effective monitoring mechanism depends on percentage of shares they hold. Block-holders and institutional investors represent a great source of power and threat for management. On the one hand, their dissatisfaction about managerial performance may remove management through exercising voting right, on the other hand, their collective exit would severely push down the stock price causing massive losses (Solomon 2010).

The study assesses ownership concentration by the percentage of total shares held by majority (Mir and Nishat 2004, Hastori et al. 2015, and Shahwan 2015). This continuous measure will be used in the fundamental analysis, whereas in the robustness check, ownership concentration will be introduced as an indicator variable whose value equals 1 if concentration is greater than or equal $50 \%$, and zero otherwise (Imam and Malik 2007, and Al-Rassas and Kamardin 2016). 


\section{3-2-4 Control Variables}

Following prior research (e.g., Wang and Deng 2006, Coles et al. 2008, Shahwan 2015, Al-Rassas and Kamardin 2016, and others ), the following variables are included in the regression in order to control for firms' particular conditions and to avoid specification errors in the multivariate analyses:

1- Size; where larger firms tend to have higher investment efficiency (lower deviations from expected investment levels) and are more likely to be a specialized audit client. Size is measured as the natural logarithm of firm's total assets (Peasnell et al. 2005, Ismail et al. 2009, Reichelt and Wang 2010, Khanqah 2015). Firm size is expected to be positively related to investment efficiency.

2- Leverage; where high leveraged firms tend to have lower firm performance because of using more discretionary accruals to avoid covenant violation. Leverage is measured as firm's total liability deflated by book value of equity (Klien 2002, Davidson et al. 2005, and Al-Rassas and Kamardin 2016). Leverage is expected to be negatively associated with investment efficiency.

3- Market-to-book ratio; where firms with higher MTB tend to invest efficiently, and most probable to be a specialized auditor client, and have a concentrated ownership. MTB is measured by the ratio of market value to the book value of common equity (Biddle et al. 2009, Khanqah 2015, and Shahwan 2015). MTB is expected to be positively associated with investment efficiency.

4- Return on investment; measured as earnings before interest and tax divided by total investment. It measures profitability, where firms with high growth opportunities are more likely to be high profitable firms (Shahwan 2015 and Al-Rassas and Kamardin 2016). It is expected that return on investment to be positively related to investment efficiency.

\section{3-3 Regression Models}

As illustrated earlier, external monitoring mechanisms represented in external audit are supposed to enhance firm performance indicators, one of which is in- 
vestment efficiency. Since it's well accepted that specialist auditors provide higher quality audit service, which in turn, promote performance and growth, then the first research hypothesis predicts a positive (negative) relation between auditor industry specialization and investment efficiency (deviations from normal investment level). Put it another way, firms audited by specialized auditors would show lower deviations from expected investment level.

The second research hypothesis predicts that ownership concentration is positively related to investment efficiency. This prediction is based on the fact that Egyptian context lacks legal protection and enforcement mechanisms, then ownership concentration can serve as alternative internal governance tool in promoting investment. That is, ownership concentration improves investment efficiency.

Specifically, the following model is employed to test both first and second hypotheses:

Over/under invt $\mathrm{i}_{\mathrm{i}, \mathrm{t}}=\beta_{0}+\beta_{1} \mathrm{MS}_{-}$assets $\mathrm{s}_{\mathrm{i}, \mathrm{t}}+\beta_{2} \mathrm{OWCO}_{\mathrm{i}, \mathrm{t}}+\beta_{3-6}$ Controls $_{\mathrm{i}, \mathrm{t}}+\dot{\varepsilon}_{\mathrm{i}, \mathrm{t}}---(3)$

Where;

Over/under invt $t_{i, t}$ are the residuals of equation (1); resulting from regressing investment on sales growth. It denotes abnormal investment for firm $\mathrm{i}$ in year $\mathrm{t}$. For fundamental analysis purposes, absolute values will be considered as primary dependent variable.

MS_assets is the auditor market share calculated using equation (2); based on total assets of clients relative to total assets of industry.

OWCO is total shares held by majority relative to firm's total shares.

Control variables are as previously discussed; namely size, leverage, MTB, and return on investment.

Based on the argument that an interaction relationship may arise between auditor industry specialization and ownership concentration, study's third hypothe- 
sis predicts that specialist auditors moderate the relationship between ownership concentration and investment efficiency.

The following is the linear-multiple regression analysis expressing such relation; where equation (3) is expanded to include the interaction term of two variables:

\section{Over/under invt $\mathrm{i}_{\mathrm{i}, \mathrm{t}}=\beta_{0}+\beta_{1}$ MS_assets $_{\mathrm{i}, \mathrm{t}}+\beta_{2}$ OWCO $_{\mathrm{i}, \mathrm{t}}+\beta_{3}$} MS_assets $\mathrm{i}_{\mathrm{i}, \mathrm{t}} * \mathrm{OWCO}_{\mathrm{i}, \mathrm{t}}+\beta_{4-6}$ Controls $_{\mathrm{i}, \mathrm{t}}+\dot{\varepsilon}_{\mathrm{i}, \mathrm{t}}-----------(4)$

For the interaction term, it's expected that its coefficient $\left(\beta_{3}\right)$ to be negative if the relation between auditor specialization and ownership concentration turns out to be complementary, whereas the coefficient is expected to be positive if the two variables turn to be substitutes.

\section{4- Empirical Results}

Descriptive statistics for study main and control variables are presented in Table (2).

\section{Table (2): Descriptive Statistics of Study Variables}

( $\mathrm{N}=592$ observations)

\begin{tabular}{|c|c|c|c|c|c|c|c|c|c|}
\hline Variable & Mean & $\begin{array}{c}\text { Std. } \\
\text { Dev. }\end{array}$ & Min & Q1 & Median & Q3 & Max & Kurtosis & Skewness \\
\hline Abs resd & 0.0337 & 0.0604 & 0.0001 & 0.0147 & 0.0214 & 0.0258 & 0.8034 & 9.2361 & 2.89 \\
\hline MS_assets & 0.2012 & 0.2335 & 0.0003 & 0.010 & 0.0644 & 0.4709 & 0.6481 & -1.07 & 0.812 \\
\hline MS_Sales & 0.2078 & 0.2601 & -0.0001 & 0.0054 & 0.0492 & 0.4643 & 0.7513 & -1.03 & 0.848 \\
\hline \% OWCO & 0.4870 & 0.2785 & 0.0200 & 0.2300 & 0.4550 & 0.7500 & 0.9900 & -1.202 & 0.192 \\
\hline Size & 19.902 & 1.6095 & 16.2448 & 18.677 & 19.779 & 20.949 & 24.334 & -0.308 & 0.470 \\
\hline Lev & 2.2491 & 3.3397 & 0.0005 & 0.2933 & 0.9278 & 2.3844 & 24.694 & 8.356 & 2.625 \\
\hline MTB & 1.9882 & 2.4486 & 0.0046 & 0.6245 & 1.2380 & 2.2190 & 24.810 & 2.157 & 2.116 \\
\hline ROI & 111.04 & 153.35 & -1530.9 & -0.035 & 2.6905 & 23.159 & 21158 & 9.126 & 2.914 \\
\hline
\end{tabular}


Table (2) shows that absolute value of abnormal investment has an average and median of 0.03 and 0.02 respectively, distributed almost normal (9.23). Market share of specialized auditors, irrespective of the measure (client sales revenues or total assets), has a mean of 0.2 , indicating that on average, the dominant auditor serves $20 \%$ of the firms in the industry. The maximum market share of the dominant auditor is $65 \%$ and $75 \%$ by assets and sales respectively, suggesting the absolute existence of dominant auditors in certain industries. For ownership concentration, the mean and median are 0.49 and 0.46 , indicating that almost 50\% of sample firms are highly concentrated firms. The maximum \% of ownership concentration (99\%), suggesting the existence of complete concentration in certain firms. Main variables show low differences between their means and medians, as well as low standard deviation, denoting minor dispersion for these metrics. With regards to control variables, all show low dispersion cited in low standard deviations and ranges, except for return on investment which exhibit the highest dispersion among all.

To check for normality, skewness and kurtosis tests were conducted, with a threshold of +3 for skewness as recommended by Hair et al. (2006), and threshold of +10 for kurtosis, as suggested by Kline (1998). Values appearing on Table (2) indicate that data are normally distributed.

Table (3): Correlation Matrix of Study Variables

\begin{tabular}{|l|c|c|c|c|c|c|c|c|}
\hline Variables & Abs resd & MS_assets & MS_sales & \%OWCO & Size & Lev & MTB & ROI \\
\hline Abs resd & 1 & & & & & & & \\
\hline MS_assets & -0.065 & 1 & & & & & & \\
\hline MS_Sales & -0.055 & $0.969^{* *}$ & 1 & & & & & \\
\hline \% OWCO & 0.055 & $0.130^{* *}$ & $0.131^{* *}$ & 1 & & & & \\
\hline Size & $-0.131^{* *}$ & $0.401^{* *}$ & $0.377^{* *}$ & $0.168^{* *}$ & 1 & & & \\
\hline Lev & 0.029 & 0.018 & 0.037 & $0.397^{* *}$ & $0.332^{* *}$ & 1 & & \\
\hline MTB & -0.061 & 0.052 & 0.037 & $0.189^{* *}$ & 0.047 & $0.228^{* *}$ & 1 & \\
\hline ROI & -0.016 & 0.082 & 0.069 & -0.007 & 0.051 & -0.044 & 0.046 & 1 \\
\hline
\end{tabular}

**Correlation is significant at the 0.01 level (2-tailed). 
Table (3) illustrates Pearson correlation coefficients among study variables. Values confirm the absence of multi-collinearity, where no coefficient exceeds 0.8 (Hair et al. 2006). Moreover, I examine variance inflation factors (VIFs) for variables to make sure they show low values (less than 10) so that the effect of multi-collinearity is avoided. Only for auditors' market share measures based on assets and on sales, the coefficient turns out to be 0.97 (and VIF $>10$ ), however, these two variables are used alternatively in the regression (MS_assets in the fundamental analysis and MS_sales in the sensitivity analysis). Industry specialist auditor proxies are almost perfectly correlated, revealing that firms with more total assets generate higher sales. Additionally, auditor industry specialization proxies are negatively correlated with absolute residuals of investment model. This reveals that firms audited by specialists are less likely to deviate from investment expected level. Ownership concentration is positively correlated with abnormal investment, indicating that firms with concentrated ownership tend to deviate more from expected investment levels. Also, ownership concentration shows a significant positive correlation with auditor industry specialization proxies, denoting that firms with concentrated ownership tend to hire specialized auditors. With respect to control variables, only size show significant correlation coefficients with main variables at $1 \%$ level, which is not unexpected.

\section{4-1 Fundamental Analysis}

Basic analysis uses absolute value of residuals from investment decision model as dependent variable. Moreover, two models are employed; first model to detect the separate effect of independent variables (equation (3)), and second model to detect the interaction effect of independent variables (equation (4)) on investment efficiency. That is, first model investigates the validity of the first two hypotheses, whereas, second model tests for the third hypothesis. 


\section{Results of Absolute Residuals}

Table (4): Results of Regression Analysis for the effect of Audit Specialization and Ownership Concentration on Investment Efficiency

\begin{tabular}{|c|c|c|c|c|c|c|}
\hline \multicolumn{4}{|c|}{ Model (1) } & \multicolumn{3}{|c|}{ Model (2) } \\
\hline Variable & $\boldsymbol{\beta}$ & $\mathbf{t}$ & Sig. & $\bar{\beta}$ & $\mathbf{t}$ & Sig. \\
\hline Constant & 0.152 & 3.716 & 0.000 & 0.152 & 3.701 & 0.000 \\
\hline MS_assets & -0.08 & -0.151 & 0.048 & -0.036 & -0.314 & 0.05 \\
\hline$\%$ OWCO & 0.06 & 1.203 & 0.023 & 0.051 & 0.761 & 0.044 \\
\hline $\begin{array}{l}\text { MS_assets } \\
* \% \text { OWCO }\end{array}$ & & & & 0.033 & 0.276 & 0.0783 \\
\hline Size & -0.163 & -2.94 & 0.003 & -0.161 & -2.874 & 0.004 \\
\hline Lev & 0.074 & 1.33 & 0.038 & 0.075 & 1.337 & 0.038 \\
\hline MTB & -0.083 & -1.669 & 0.096 & -0.082 & -1.658 & 0.098 \\
\hline ROI & 0.001 & 0.016 & 0.987 & 0.000 & -0.001 & 0.999 \\
\hline $\mathbf{N}$ & \multicolumn{3}{|c|}{592} & \multicolumn{3}{|c|}{592} \\
\hline $\mathrm{R}-\mathrm{Sq}$ & \multicolumn{3}{|c|}{$18 \%$} & \multicolumn{3}{|c|}{$18.2 \%$} \\
\hline $\mathbf{F}$ & \multicolumn{3}{|c|}{2.411} & \multicolumn{3}{|c|}{2.073} \\
\hline P-value & \multicolumn{3}{|c|}{0.027} & \multicolumn{3}{|c|}{0.045} \\
\hline
\end{tabular}

Table (4) presents results of regressing absolute residuals of investment model on auditor market share based on total assets and percentage of ownership concentration. Results indicates the significance of the two models ( $\mathrm{P}$-value $<5 \%$ ). $\mathrm{R}-\mathrm{Sq}$ value suggests that independent variables account for $18 \%$ of variations in absolute residuals. In model (1), sign and significance of MS_assets coefficient ($0.08,0.048)$ implies a significant negative relationship between auditor specialization and abnormal investment. Stated differently, specialist auditors motivate their clients to deviate less from expected investment levels. This entails the Acceptance of the first hypothesis predicting that specialized auditors promote investment efficiency. This result supports evidence provided by previous studies, for example, Balsam et al. (2003), Krishnan (2003), Dunn and Mayhew (2004), Lim and Tan (2009), and Bae and Choi (2012); where all reach a positive impact 
of auditor specialization on firm performance measures, including investment efficiency.

In addition, \%OWCO has a positive significant coefficient $(0.06,0.023)$, indicating a significant positive relationship between ownership concentration and abnormal investment. That is, highly concentrated firms show more deviations from expected investment levels. Therefore, the second hypothesis, predicting that ownership concentration enhances investment efficiency, is Rejected at 5\% significance level. This result agrees with some of prior studies, such as, Claessens et al. (2000), Lasfer (2006), Wang (2006), Zhong et al. (2007), and Chen et al. (2017); which support a negative impact of ownership concentration on firm performance proxies. Nevertheless, documented result contradicts other studies advocating a positive role for ownership concentration (e.g., Azofra et al. 2003, Imam and Malik 2006 Teshima and Shuto 2006).

In Model (2), the positive insignificant coefficient of interaction term MS_assets * \% OWCO $(0.033,0.0783)$, indicate a substitution relationship between auditor specialization and ownership concentration, yet insignificant. This implies the Rejection of third hypothesis predicting an interaction effect of auditor specialization and ownership concentration. Hence, auditor industry specialization fails to moderate the relationship between ownership concentration and investment efficiency. Therefore, firms cannot lessen the negative effect of ownership concentration on investment through hiring specialized auditors. This result contradicts evidence provided by Brunninge et al. (2007), Florackis (2008), Sulong and Nor (2010) and Khanqah (2015); which support the existence of interaction among various corporate governance mechanisms.

For control variables, size shows negative significant coefficients under the two models, implying that larger firms tend to have less abnormal investment levels. That is, size is positively related to investment efficiency. Under the two models, leverage shows positive significant coefficients or more deviations from expected investment levels, revealing that high degree of financial leverage hinders investment efficiency. 
Both MTB and ROI fail to show significant coefficients, denoting their minor role in investment decision model for the sample firms.

\section{4-2 Additional Analysis}

As a robustness check, observations are segregated according to absolute residuals into: over-investment (positive deviations), and under-investment (negative deviations); to trace the differential impact of independent variables on investment behavior. This approach has been implemented by previous studies, such as, Biddle et al. (2009), Bae and Choi (2012), and Khanqah (2015). Splitting procedure shows that only $30 \%$ of the sample observations belong to overinvestment group, whereas an overriding majority of observations are underinvesting. This intuitive result may indicate difficulty faced by Egyptian firms in obtaining external financing, and reflect a high degree of uncertainty in business culture. This creates a problem of underinvestment rather than overinvestment.

It's worth mentioning that almost the same subdivision result exists in the Iranian sample firms employed by Khanqah (2015), where only $36 \%$ of the sample was overinvesting. Nevertheless, this was not the case for the Korean sample firms employed by Bae and Choi (2012), where overinvestment represents 65\% of the sample. This well confirms that the cultural factor does affect investment behavior. 
The following two tables illustrate the regression outcomes for the two subgroups.

\section{4-2-1 Over-investment Results}

Table (5): Results of Regression Analysis for the effect of Audit Specialization and Ownership Concentration on Investment Efficiency For Over-Investing Firms

\begin{tabular}{|c|c|c|c|c|c|c|}
\hline \multicolumn{4}{|c|}{ Model (1) } & \multicolumn{3}{|c|}{ Model (2) } \\
\hline Variable & $\beta$ & $\mathbf{t}$ & Sig. & $\beta$ & $\mathbf{t}$ & Sig. \\
\hline Constant & 0.277 & 2.037 & 0.044 & 0.276 & 2.020 & 0.046 \\
\hline MS_assets & -0.007 & -0.067 & 0.095 & -0.132 & -0.443 & 0.0658 \\
\hline$\% \mathrm{OWCO}$ & 0.102 & 0.925 & 0.036 & 0.064 & 0.459 & 0.0647 \\
\hline $\begin{array}{l}\text { MS_assets } \\
* \% O W C O\end{array}$ & & & & 0.144 & 0.449 & 0.0654 \\
\hline Size & -0.183 & -1.559 & 0.122 & -0.178 & -1.496 & 0.137 \\
\hline Lev & 0.029 & 0.257 & 0.797 & 0.027 & 0.235 & 0.814 \\
\hline MTB & -0.144 & -1.550 & 0.124 & -0.138 & -1.461 & 0.147 \\
\hline ROI & -0.034 & -0.368 & 0.713 & -0.036 & -0.394 & 0.695 \\
\hline $\mathbf{N}$ & \multicolumn{3}{|c|}{$178(30 \%)$} & \multicolumn{3}{|c|}{178} \\
\hline $\mathrm{R}-\mathrm{Sq}$ & \multicolumn{3}{|c|}{$21.1 \%$} & \multicolumn{3}{|c|}{$21.5 \%$} \\
\hline $\mathbf{F}$ & \multicolumn{3}{|c|}{0.910} & \multicolumn{3}{|c|}{0.804} \\
\hline P-value & \multicolumn{3}{|c|}{0.049} & \multicolumn{3}{|c|}{0.05} \\
\hline
\end{tabular}

Table (5) reports the results of regression relating over-investment or positive deviations from normal investment levels and independent variables, auditor market share based on assets and percentage of ownership concentration. Both models express significance with P-values less than 5\%. Results of Model (1) uncover that specialist auditors fail to discourage over-investment. Specifically, MS_assets show negative insignificant coefficient $(-0.007,0.095)$, demonstrating that specialized auditors have no impact on investment efficiency for overinvesting firms, reversing results of absolute residuals in fundamental analysis. Thus, the first hypothesis is Rejected for over-investment. On the contrary, 
ownership concentration has a positive significant coefficient $(0.102,0.036)$, confirming the fundamental results reached for absolute residuals; which imply that ownership concentration deter investment efficiency. This motivates the Rejection of the second hypothesis for over-investment.

Regarding the interaction effect, Model (2)'s outcomes verify the validity of absolute residuals result, where interaction term turns out to positive and insignificant $(0.144,0.0654)$, implying the Rejection of third hypothesis for overinvestment as well.

In sum, for over-investing firms, evidence provided implies that ownership concentration participates in such deviations. Moreover, specialized auditors not only are incapable of discouraging over-investment, but also fail to moderate the effect of ownership concentration on investment efficiency.

\section{4-2-2 Under-investment Results}

Table (6): Results of Regression Analysis for the effect of Audit Specialization and Ownership Concentration on Investment Efficiency For Under-Investing Firms

\begin{tabular}{|c|c|c|c|c|c|c|}
\hline \multicolumn{4}{|c|}{ Model (1) } & \multicolumn{3}{|c|}{ Model (2) } \\
\hline Variable & $\beta$ & $\mathbf{t}$ & Sig. & $\boldsymbol{\beta}$ & $\mathbf{t}$ & Sig. \\
\hline Constant & -0.065 & -3.893 & 0.000 & -0.065 & -3.951 & 0.000 \\
\hline MS_assets & -0.085 & 1.398 & 0.0163 & -0.116 & -0.951 & 0.034 \\
\hline$\% \mathrm{OWCO}$ & 0.098 & -1.635 & 0.0103 & 0.190 & -2.477 & 0.014 \\
\hline $\begin{array}{l}\text { MS_assets } \\
* \% O W C O\end{array}$ & & & & 0.245 & 1.905 & 0.050 \\
\hline Size & 0.163 & 2.608 & 0.010 & 0.177 & 2.830 & 0.005 \\
\hline Lev & -0.154 & -2.410 & 0.017 & -0.145 & -2.273 & 0.024 \\
\hline MTB & 0.090 & 1.546 & 0.123 & 0.089 & 1.531 & 0.127 \\
\hline ROI & -0.024 & -0.422 & 0.674 & -0.030 & -0.535 & 0.593 \\
\hline $\mathbf{N}$ & \multicolumn{3}{|c|}{$414(70 \%)$} & \multicolumn{3}{|c|}{414} \\
\hline $\mathrm{R}-\mathrm{Sq}$ & \multicolumn{3}{|c|}{$26.6 \%$} & \multicolumn{3}{|c|}{$28.6 \%$} \\
\hline $\mathbf{F}$ & \multicolumn{3}{|c|}{3.821} & \multicolumn{3}{|c|}{3.822} \\
\hline P-value & \multicolumn{3}{|c|}{0.001} & \multicolumn{3}{|c|}{0.001} \\
\hline
\end{tabular}


Table (6) presents the results of regression relating under-investment or negative deviations from normal investment levels and independent variables under the two models. Outcomes of Model (1) point to negative significant coefficient $(-0.085,0.0163)$ for MS_assets, indicating a constructive role for specialized auditors in investment decisions. This confirms the fundamental analysis result, and implies the Acceptance of first hypothesis for under-investment. Also, the fundamental analysis implication for the second hypothesis remains valid. Coefficient of \%OWCO appears positive and significant $(0.098,0.0103)$, denoting an adverse impact of ownership concentration on investment behavior. Again, this verifies the fundamental analysis result, and implies the Rejection of second hypothesis for under-investment.

With respect to Model (2), the positive significant coefficient of interaction term MS_assets * \% OWCO $(0.245,0.05)$, indicating that auditor specialization and ownership concentration can be perceived as substitutes only in case of under-investing firms. This implies the Acceptance of third hypothesis predicting an interaction effect of auditor specialization and ownership concentration, which contradicts inference of fundamental analysis regarding the third hypothesis.

Overall, for under-investing firms, evidence provided suggests that ownership concentration participates in such deviations. Additionally, specialized auditors are capable of both limiting under-investment, and substituting for the adverse effect of ownership concentration on investment efficiency.

Results reached disagree with those provided by Bae and Choi (2012) which support a positive role for industry specialist auditors in discouraging inefficient investment, especially overinvestment relative to underinvestment. Such difference may be partially attributable to difference in percentage representing overand under-investing sample firms.

Moreover, my results disagree with Khanqah (2015), which provides evidence supporting the interaction effects between corporate governance mechanisms, where specialized auditors found to enhance the effectiveness of board 
independence (the other corporate governance tool) in reducing both over and under investment deviations.

\section{4-3 Sensitivity Analysis}

In an attempt to lend more credence to my results, different assessments are used for independent variables, an approach followed by many of prior studies (Mayhew and Wilkins 2003, Bae and Choi 2012, and Al-Rassas and Kamardin 2016). In fundamental analysis, industry auditor specialization is constructed based on the market share calculated by clients' total assets, and ownership concentration is measured as a percentage of total shares held by majority.

As a robustness check, I will re-perform the analysis employing different proxies. Industry auditor specialization is assessed based on the market share calculated by clients' sales revenues. Whereas ownership concentration is introduced as an indicator variable whose value equals 1 if concentration is greater than or equal $50 \%$, and zero otherwise.

\section{Table (7): Results of Regression Analysis for the effect of Audit Specialization (Sales) and Ownership Concentration (Dummy) on Investment Efficiency}

\begin{tabular}{|c|c|c|c|c|c|c|}
\hline \multicolumn{3}{|c|}{ Model (1) } & \multicolumn{3}{|c|}{ Model (2) } & \\
\hline Variable & $\beta$ & $\mathbf{t}$ & Sig. & $\beta$ & $\mathbf{t}$ & Sig. \\
\hline Constant & 0.143 & 3.524 & 0.000 & 0.147 & 3.559 & 0.000 \\
\hline MS_Sales & -0.021 & -0.398 & 0.030 & -0.015 & -0.170 & 0.043 \\
\hline DUMOWCO & 0.080 & 1.476 & 0.014 & 0.102 & 1.504 & 0.013 \\
\hline $\begin{array}{l}\text { MS_Sales } \\
\text { *DUMOWCO }\end{array}$ & & & & 0.051 & 0.537 & 0.067 \\
\hline Size & -0.149 & -2.691 & 0.007 & -0.156 & -2.741 & 0.006 \\
\hline Lev & 0.066 & 1.163 & 0.245 & 0.065 & 1.151 & 0.250 \\
\hline
\end{tabular}




\begin{tabular}{|l|c|c|c|c|c|c|}
\hline MTB & -0.079 & -1.601 & 0.110 & -0.081 & -1.631 & 0.104 \\
\hline ROI & -0.001 & -0.025 & 0.980 & -0.001 & -0.023 & 0.982 \\
\hline N & \multicolumn{3}{|c|}{592} & \multicolumn{3}{|c|}{592} \\
\hline R-Sq & \multicolumn{3}{|c|}{$2.2 \%$} & \multicolumn{3}{|c|}{2.106} \\
\hline F & \multicolumn{3}{|c|}{2.413} & \multicolumn{3}{|c|}{0.042} \\
\hline P-value & 0.026 & & \\
\hline
\end{tabular}

Table (7) reports results of regressing absolute residuals of investment model on auditor market share based on sales and dummy variable for ownership concentration. Results indicates the significance of the two models ( $\mathrm{P}$-value $<5 \%$ ). $\mathrm{R}-\mathrm{Sq}$ values suggest that the model specification is reasonable. In model (1), sign and significance of MS_Sales coefficient $(-0.021,0.03)$ implies that specialist auditors encourage their clients to deviate less from normal investment levels. The finding is almost identical to what obtained in fundamental analysis, which is not unexpected considering the extent that sales revenues are closely correlated with total assets. Therefore, results confirm outcomes of fundamental analysis and suggest the Acceptance of the first hypothesis predicting that specialized auditors promote investment efficiency.

Moreover, DUMOWCO has a positive significant coefficient $(0.08,0.014)$, indicating that high ownership concentration enhances more deviations from expected investment levels. Therefore, fundamental analysis results are verified and the second hypothesis is Rejected.

Regarding Model (2), the positive insignificant coefficient of interaction term MS_Sales * DUMOWCO $(0.051,0.067)$ implies the Rejection of third hypothesis predicting an interaction effect of auditor specialization and ownership concentration, and confirms fundamental analysis. Hence, firms with high concentration of ownership would show more deviations from expected investment levels, regardless of whether they're audited by specialists or non-specialists. 
Noteworthy, the consistency of fundamental and sensitivity results corresponds that in Mayhew and Wilkins (2003), and Bae and Choi (2012), in spite of disagreement of the results themselves.

\section{5- SUMMARY AND CONCLUSION}

This study belongs to the wide domain of research examining interaction effect of corporate governance mechanisms on firm performance. I investigate the impact of auditor specialization and ownership concentration on investment efficiency for a sample of 592 firm-year observations from 2011 to 2018. Research hypotheses are premised on the well accepted belief that corporate governance motivates financial performance, and thus, predict a positive significant association between corporate governance tools, namely audit quality and ownership concentration, and investment efficiency.

Investment efficiency is inversely measured through identifying deviations, positive and negative, from expected investment level. Therefore, both over-and under-investment will be perceived as investment inefficiency. Auditor industry specialization, denoting audit quality, is assessed using industry market share based on clients' total assets. Ownership concentration is measured as a percentage of total shares held by majority. In order to account for firms' specific characteristics, four control variables were included in the regression; firm size, leverage, market-to-book ratio, and return on investment.

The study hypothesizes that, first, auditor industry specialization enhances investment efficiency, where it's predicted that firms audited by specialists would show higher levels of investment efficiency or less deviations from expected investment level. Second, higher levels of ownership concentration are more likely to be associated with higher investment efficiency. Third, specialized auditors are expected to moderate the relation between ownership concentration and investment efficiency.

In the fundamental analysis, absolute value of residuals from investment decision model is used as dependent variable. I employ two models; the first model to detect the separate effect of independent variables, and the second model to 
detect the interaction effect of independent variables on investment efficiency. As an additional analysis, observations are segregated according to absolute residuals into: over-investment (positive deviations), and under-investment (negative deviations).

Sensitivity analysis uses different measures for assessing independent variables. Industry auditor specialization is assessed based on the market share calculated by clients' sales revenues. Whereas ownership concentration is introduced as an indicator variable whose value equals 1 if concentration is greater than or equal $50 \%$, and zero otherwise.

\section{Conclusions}

Results of fundamental analysis imply the acceptance of the first hypothesis predicting a positive significant association between audit specialization and investment efficiency indicator. Nevertheless, through performing my additional analysis, this hypothesis has been proven valid only for under-investment, but not for over-investment. Moreover, Results of sensitivity analysis confirms the fundamental tests and accepts the first hypothesis of specialists' positive role in promoting investment. This entails that hiring a specialized auditor would motivate clients to invest efficiently. It's worth mentioning that same findings were reached by a number of studies, such as Balsam et al. (2003), Krishnan (2003), Dunn and Mayhew (2004), Lim and Tan (2009), Bae and Choi (2012), and Khanqah (2015).

The second hypothesis predicts a positive significant association between ownership concentration and investment efficiency. This hypothesis was rejected on all levels and tests. That is, fundamental test rejects the positive role of ownership concentration using absolute residuals. Also, additional test rejects such hypothesis for both over-and under-investment. Even when employing different proxies in sensitivity test, this hypothesis in again rejected. This implies that ownership concentration in Egyptian firms cannot be perceived as a corporate governance mechanism; on the contrary, it actually deters investment efficiency and increases deviations from expected investment levels. This finding is con- 
sistent with some of prior studies, such as, Claessens et al. (2000), Lasfer (2006), Wang (2006), Zhong et al. (2007), and Chen et al. (2017); where all suggest an adverse impact of ownership concentration on firm performance proxies.

The third hypothesis predicts an interaction effect between auditor specialization and ownership concentration. Despite the fact that this hypothesis was rejected by fundamental and sensitivity tests, it has been accepted by additional test only for under-investment, but not for over-investment. This implies that, broadly speaking, auditors, even specialists, fail to lessen the negative impact of ownership concentration on investment efficiency.

Research results can be interpreted as follows; first, audit quality is an important external corporate governance tool that can be used to push up firm performance. Auditor industry specialization, as one proxy for audit quality, has proven effective in promoting investment efficiency. Second, ownership concentration exerts a downward pressure on investment efficiency. Inferences of ownership concentration results point to the Egyptian investment culture, which distinguish it from other settings. Shedding the light on Egyptian ownership structure, high concentration represents mainly state-holding shares. The distinguishing element dominating Egyptian Stock Market has been the large-scale privatization that has taken place since the 1990s. The point is a large portion of companies listed on Egyptian Stock Exchange is formerly stated-owned companies that have been privatized. It's well documented that government ownership weakens investment efficiency (Chen and Sung 2017, and Chen et al. 2017). It's well documented that government investment decisions are more linked to political considerations, leading to inefficient outcomes.

Third, there is no integration among different corporate governance mechanisms, where auditor specialization appears passive in moderating the impact of ownership concentration on investment efficiency. As suggested by Wahba (2013), the effectiveness of one corporate governance mechanism is more likely to depend on other corporate governance tools in action. 
This paper makes several contributions to the literature, first; it adds to the extant research addressing the value of high quality audits, where it provides evidence supporting the constructive role of highly qualified specialized auditors in enhancing investment efficiency. Second, it extends evidence provided from Egyptian Stock Market on corporate governance impact on different aspects, such as financial distress (Shahwan 2015), debt and firm performance (Wahba 2014), and corporate finance (Elsayed 2011). Third, the paper complements other studies focusing on cultural factor in explaining the directions of different financial indicators. It highlights the impact of business culture in shaping deviations from normal investment levels, either positive or negative. High degree of uncertainty and difficulty in obtaining external finance pave the way for underinvestment to override the scene in the Egyptian financial market.

\section{Recommendations}

Evidence provided has significant implications. First, for listed companies, reliance on specialized auditors would enhance investment efficiency. Especially for underinvesting firms, specialist auditors would add much to firm performance. Second, for policy makers, ownership structure in Egyptian companies should be revised. Government must withdraw its hand to allow more ownership distribution. Even though institutional ownership does exist in Egyptian Stock Market, it seems that its positive impact is diluted given the heavily stateholding concentration.

Third, for corporate governance regulators, a platform should be designed to prescribe an integrated corporate governance structure. Regulators should guide firms in coordinating various corporate governance mechanisms, including board of directors (independence, responsibilities, committees, and structure), external audit quality, transparency and disclosure, internal control procedures, and shareholders' rights. Once integration exists, different mechanisms would complement one another so that corporate governance objectives are attained. 


\section{Future Research}

Despite the overwhelming literature addressing the impact of corporate governance on firm performance and market indicators, it remains rich area for future research. Researchers would employ different dimensions of corporate governance mechanisms, and test for interaction effect among these tools. Moreover, researchers may introduce indicators for social responsibility and sustainability in their analysis. Also, researchers may employ other investment decision models, incorporating financial and non-financial factors. Lastly, research may be directed towards examining the relation between perceived and actual audit quality in family and non-family firms and investment efficiency.

\section{References}

Abd-Elsalam, O.H. and Weetman, P. (2003), "Introducing international accounting standards to an emerging capital market: relative familiarity and language effect in Egypt", Journal of International Accounting, Auditing \& Taxation12 (1): 63-84.

Al-Rassas, A., and Kamardin, H. (2016). Earnings quality and audit attributes in high concentrated ownership market. Corporate Governance 16 (2): 377-399.

Azofra, V., Castrillo, L. and del Mar Delgado, M., (2003). Ownership concentration, debt financing and the investment opportunity set as determinants of accounting discretion: Empirical evidence from Spain. Spanish Journal of Finance and Accounting 32(115): 215-255.

Bae, G.S. and Choi, S.U., (2012). Do industry specialist auditors improve investment efficiency?. Available at SSRN 2145191.

Bae, G.S., Choi, S.U., Dhaliwal, D.S. and Lamoreaux, P.T., (2017). Auditors and client investment efficiency. The Accounting Review 92(2):19_40. 
Balsam, S., Krishnan, J., Yang, J.S. (2003). Auditor industry specialization and earnings quality. Auditing: A Journal of Practice and Theory 22 (2): 71-97.

Becker, C., DeFond, M., Jiambalvo, J., \& Subramanyam, K. (1998). The effect of audit quality on earnings management. Contemporary Accounting Research 15: 1-24.

Beeler, J.D., and Hunton, J.E. (2002). Contingent Economic Rents: Insidious Threats to Audit Independence. Advances in Accounting Behavioral Research 5: 3-17.

Benkraiem, R. (2009), "Does the presence of independent directors influence accruals

management?”, Journal of Applied Business Research 25: 77-86.

Bergstresser, D., and Philippon, T. (2006). CEO Incentives and Earnings Management. Journal of Financial Economics 80: 511-529.

Biddle, G. C., and G. Hilary. (2006). Accounting quality and firm-level capital investment. The Accounting Review 81 (5): 963-982.

Biddle, G. C., G. Hilary, and R.S. Verdi. (2009). How does financial reporting quality relate to investment efficiency? Journal of Accounting and Economics 48: 112-131.

Bin-Zulkafli, A., Adul Samad, M. and Ismail, M. (2007), "Corporate governance in Malaysia", Malaysian Institute of Corporate Governance 1 (1): $18-30$

Brown, J.R., Falaschetti, D. and Orlando, M.J., (2008). Auditor independence and earnings quality: Evidence for market discipline vs. SarbanesOxley proscriptions. FSU College of Law. Law and Economics $\mathrm{Pa}-$ per: $7-33$. 
Brunnige, O., Nordqvist, M., and Wiklund, J. (2007). Corporate governance and strategic change in SMEs: The effects of ownership, board composition, and top management teams. Small Business Economics 29: 295-308.

Burkart, M., Panunzi, F. and Shleifer, A., (2003). Family firms. The journal of finance, 58(5): 2167-2201.

Bushee, B.J., (1998). The influence of institutional investors on myopic R\&D investment behavior. Accounting review 2 (1):305-333.

Bushee, B.J. and Noe, C.F., (2000). Corporate disclosure practices, institutional investors, and stock return volatility. Journal of accounting research 1 (2): 171-202.

Carana. (2002). Privatization in Egypt. Quarterly Review (January-March 2002) Provided to the United States Agency for International Development by Carana Corporation under the USAID Monitoring Services Project.

Carcello, J., and Nagy, A.L. (2004). Client Size, Auditor Specialization and Fraudulent Financial Reporting. Managerial Auditing Journal 19 (5): 651-668.

Charitou, A., Lambertides, N., and Trigeorgis, L. (2007). Earnings Behaviour of Financially Distressed Firms: The Role of Institutional Ownership. ABACUS 43 (3).

Chen, R., El Ghoul, S., Guedhami, O. and Wang, H., (2017). Do state and foreign ownership affect investment efficiency? Evidence from privatizations. Journal of Corporate Finance, 42: 408-421.

Chen, N., Sung, H.C. and Yang, J., (2017). Ownership structure, corporate governance and investment efficiency of Chinese listed firms. Pacific Accounting Review. 
Cheng, C.S., and Reitenga, A. (2009). Characteristics Of Institutional Investors And Discretionary Accruals. International journal of Accounting and Information Management 17 (1): 5-26.

Cheng, M., Dhaliwal, D. and Zhang, Y., (2013). Does investment efficiency improve after the disclosure of material weaknesses in internal control over financial reporting? Journal of Accounting and Economics, 56(1): 1-18.

Chia, Y.M., Lapsley, I., and Lee, H.W. (2007). Choice of Auditors and Earnings Management During the Asian Financial Crisis. Managerial Auditing Journal 22 (2): 177-196.

Claessens, S., Djankov, S., and Lang, H.P. (2000). The Separation of Ownership and Control in East Asian Corporations. Journal of Financial Economics 58: 81-112.

Coles, J., Daniel, N., and Naveen, L. (2008). Boards: Does One Size Fit All? Journal of Financial Economics 87: 329-356.

Crabtree, A.D., Brandon, D.M., and Maher, J.J. (2006). The impact of auditor tenure on initial bond ratings. Advanced in Accounting 22: 97-121.

Davidson, R., Goodwin-Stewart, J. and Kent, P. (2005). "Internal governance structures and earnings management", Accounting \& Finance 45 (2): 241-267.

Dopuch, N. and Simunic, D. (1980). The Nature of Competition in the Auditing Profession: A Descriptive and Normative View, in Regulation and the Accounting Profession, ed J.W. Buckley and J.F. Weston, Lifetime Learning Publication, NY: 77-94.

Dunn, K.A. and Mayhew, B.W., (2004). Audit Industry Specialization and Client Disclosure Quality. Review of Accounting Studies 9 (2): 35-58. 
Elsayed, K. (2011), "Board size and corporate performance: the missing role of board leadership structure”, Journal of Management and Governance 15 (3): 415-446.

Elsayed, K. and Wahba, H. (2013), "Reinvestigating the relationship between ownership structure and inventory management: a corporate governance perspective", International Journal of Production Economics 143 (1): 207-218.

Ferreira, Miguel, Pedro, P., and Matos. (2007). The Colors of Investors' Money: The Role of Institutional Investors around the World. The Journal of Financial Economics 56: 311-325

Florackis, C. 2008. Agency costs and corporate governance mechanisms: Evidence from UK firms. International Journal of Managerial Finance 4 (1): 37-59.

Florackis, C., Kostakis, A. and Ozkan, A. (2009), "Managerial ownership and performance", Journal of Business Research 62 (12):1350-1357.

Francis, J., and Krishnan, J. (1999). Accounting Accruals and Auditor Reporting Conservatism. Contemporary Accounting Research 16: 135-165.

Francis, J.R., Reichelt, K. and Wang, D., (2005). The pricing of national and city-specific reputations for industry expertise in the US audit market. The accounting review, 80(1): 113-136.

Garc1'a Lara, J.M., Garc1'a Osma, B. and Penalva, F. (2011). “Accounting conservatism and firm investment efficiency", Review of Accounting Studies

Gavious, I. (2007), Alternative perspectives to deal with auditors' agency problem, Critical Perspectives on Accounting 18: 451-467.

Ghosh, A. \& Moon, D. (2005). Audit tenure and perceptions of audit quality. The Accounting Review 80: 585-612. 
Green, W. (2008), "Are industry specialists more efficient and effective in performing analytical procedures? A multi-stage analysis", International Journal of Auditing 12 (3): 243-260.

Gul, F.A., Kim, J.B. and Qiu, A.A., (2010). Ownership Concentration, Foreign Shareholding, Audit Quality, and Stock Price Synchronicity: Evidence from China. Journal of Financial Economics 95 (3): 425-442

Hair, J.F., Tatham, R.L., Anderson, R.E. and Black, W. (2006). Multivariate Data Analysis, Pearson Prentice Hall, Upper Saddle River, NJ 6.

Hammersley, J.S. 2006. Pattern identification and industry-specialist auditors. The Accounting Review 81 (2): 309-336.

Hassab El-Naby, H., and Mosebach, M. (2005). Culture's Consequences in Controlling Agency Costs: Egyptian Evidence. Journal of International Accounting, Auditing, and Taxation 14: 19-32.

Hastori, H., Siregar, H., Sembel, R. and Maulana, A., (2015). Agency costs, corporate governance and ownership concentration: The case of agro-industrial companies in Indonesia. Asian Social Science, 11(18): 311-319.

Hodgson, T. M., Breban, S., Ford, C., Streatfield, and R. Urwin. (2000). The concept of investment efficiency and its application to investment managerial structures. The Institute of Actuaries

Huang, C.J. (2010). "Board, ownership and performance of banks with a dual board system: evidence from Taiwan", Journal of Management \& Organization 16 (2): 219-234.

Imam, M.O. and Malik, M., (2007). Firm performance and corporate governance through ownership structure: Evidence from Bangladesh stock market. International Review of Business Research Papers 3(4): 88-110. 
Ismail, W., Adibah, W., Dunstan, K. and Van Zijl, T. (2009). "Earnings quality and corporate governance following the implementation of Malaysian code of corporate governance", paper presented at the Journal of Contemporary Accounting and Economics (JCAE) and Seoul National University Joint Symposium, Seoul.

Jensen M., and Meckling, W. (1976). Theory of the firm: Managerial Behavior, Agency Costs and Ownership Structure. Journal of Financial Economics 3 (4): 305-360.

Kedia, S. and Philippon, T., (2009). The economics of fraudulent accounting. The Review of Financial Studies 22(6): 2169-2199.

Khanqah, V., T. (2015). The interaction effect of auditor industry specialization and board independence on investment efficiency. Iranian Journal of Business and Economics 2 (1).

Kline, R.B. 1998. Principles And Practice of Structural Equation Modeling, Guilford, New York, NY.

Klein, A. (2002b). Audit Committee, Board of Director Characteristics, and Earnings Management. Journal of Accounting and Economics 33 (3): 375-401.

Koh, P.S. (2003). On the Association Between Institutional Ownership and Aggressive Corporate Earnings Management in Australia. The British Accounting Review 35: 105-128.

Koh, P.S., and Hsu, G.C. (2005). Does the Presence of Institutional Investors Influence Accruals Management? Evidence from Australia. Corporate Governance: An International Review 13 (6): 809-823.

Krishnan, G.V., (2003). Does Big 6 auditor industry expertise constrain earnings management? Accounting Horizons, 19 (1): 1-16. 
Lasfer, M.A. (2006). The Interrelationship between Managerial Ownership and Board Structure. Journal of Business Finance and Accounting 33: 1006-1033.

Laux, C., and Laux, V. (2009). Board Committees, CEO Compensation, and Earnings Management. The Accounting Review 84 (3): 869-891.

Lenard, M., and B. Yu. (2012). Do earnings management and audit quality influence over-investment by Chinese companies? International Journal of Economics and Finance 4(2): 21-30.

Li, C., Y. Xie, and J. Zhou. (2010). National level, city level auditor industry specialization and cost of debt. Working paper.

Lim, C.Y. and Tan, P. M. S. (2009). Control divergence, timeliness in loss recognition, and the role of industry specialization: Evidence from around the world. Journal of Accounting, Auditing and Finance 24(2): 295-332

Lin, J.W and Hwang, M.I, (2010). Audit quality, corporate governance, and earnings management: A meta-analysis. International Journal of $\mathrm{Au}-$ diting 14 (1): 57-77.

Liu, L.Y., and Yan Peng, E. (2006). Institutional Ownership Composition and Accruals Quality. Working paper, SSRN.

Maletta, M., and Wright. A. 1996. Audit Evidence Planning: An Examination of Industry Characteristics. Auditing: A Journal of Practice \& Theory, pp. 71-86.

Mayhew, B.W., and Wilkins, M.S. (2003). Audit Firm Industry Specialization as a Differentiation Strategy: Evidence from Fees Charged to Firms Going Public. Auditing: A Journal Of Practice \& Theory 22 (2): 33.52 . 
McNichols, M. F., and S.R. Stubben. (2008). Does earnings management affect firms' investment decisions? The Accounting Review 83 (6): 15711603.

Mir, S. and Nishat, M., (2004). Corporate governance Structure and firm performance in Pakistan: An empirical study. In Second Annual Conference in Corporate Governance. Lahore University of Management Sciences, Lahore.

Myers, J.N., Myers, L.A., and Omer, C.T. (2003). Exploring the term of the auditor-client relationship and the quality of earnings: A case for mandatory auditor rotation. The Accounting Review 78 (3): 779-799.

O'Keefe, T.B., King, R.D., and Gaver, K.M. (19940. Audit Fees, Industry Specialization, and Compliance with GAAS Reporting Standards. Auditing: A Journal of Practice \& Theory 13: 41-55.

Owhoso, V.E., Messier, J.W.F., and Lynch, Jr. J.G. (2002). Error Detection by Industry-specialized Teams during Sequential Audit Review. Journal of Accounting Research 40: 883-900.

Peasnell, K.V., Pope, P.F., and Young, S. (2005). Board Monitoring and Earnings Management: Do Outside Directors Influence Abnormal Accruals? Journal of Business Finance and Accounting 32: 1131-1346.

Persons, O.S. (2007). "Corporate governance in Thailand: what has been done since the 1997 financial crisis?". International Journal of Disclosure and Governance 3 (4): 288-305.

Ragab, A., and M. Omran. (2006). Accounting Information, Value-Relevance, and Investors' Behavior in the Egyptian Equity Market. Review of Accounting and Finance 5(3): 279-297.

Reichelt, K.J., and D. Wang. (2010). National and office-specific measures of auditor industry expertise and effects on audit quality. Journal of Accounting Research 48 (3): 647-686. 
Richardson, S., (2006). Over-investment of free cash flow. Review of accounting studies 11(2-3): 159-189.

Shahwan, T.M., (2015). The effects of corporate governance on financial performance and financial distress: evidence from Egypt. Corporate Governance.

Shleifer, A., \& Vishny, R. (1989). Management entrenchment: The case of manager-specific investments. Journal of Financial Economics 25: 123-139.

Shleifer, A., and Vishny, R. (1997). Large Shareholders and Corporate Control. Journal of Political Economy 94: 96 1-88.

Simunic, D.A. and Stein, M.T. (1987). Product Differentiation in Auditing: Auditor Choice in the Market for Unseasoned New Issues. Canadian Certified General Accountants' Research Foundation Monograph.

Solomon, I., Shields, M., and Whittington, O.R. (1999). What do Industry Auditors Know? Journal of Accounting Research 37: 191-208.

Solomon, S., Reckers, P.M.J., and Lowe, D.J. (2005). The Impact of Management Image and Non-Audit Service Fees on Investors ${ }^{\text {ee }}$ Perceptions of Earnings Quality. Advances in Accounting 21:199-216.

Solomon, J., (2007). Corporate governance and accountability. John Wiley \& Sons.

Stulz, R. (1990). Managerial discretion and optimal financing policies. Journal of Financial Economics, 26(1): 3-27.

Sulong, Z. and Nor F. (2010). Corporate governance mechanisms and firm valuation in Malaysia listed firms: A panel data analysis. Journal of Modern Accounting and Auditing 6 (1): 1-19.

Sun, J. and Liu, G., (2013). Auditor industry specialization, board governance, and earnings management. Managerial Auditing Journal. 
Taylor, M. H. (2000). The effects of industry specialization on auditors' inherent risk assessments and confidence judgments. Contemporary Accounting Research 17 (4): 693-712.

Teshima, N., and Shuto, A.(2008). Managerial Ownership and Earnings Management: Theory and Empirical Evidence from Japan. Journal of International Financial Management and Accounting 19 (2): 107-132.

Wahba, H. (2014). Capital structure, managerial ownership and firm performance: Evidence from Egypt. Journal of Managerial Governance 18: 1041-1061.

Wahba, H. (2015), “The joint effect of board characteristics on financial performance: empirical evidence from Egypt", Review of Accounting and Finance 14 (1): 20-40.

Wang, D. (2006). Founding Family Ownership and Earnings Quality. Journal of Accounting Research 44 (3): 619-56.

Wang, Z.J. and Deng, X.L. (2006). "Corporate governance and financial distress: evidence from Chinese listed companies", The Chinese Economy 39 (5): 5-27.

Zgarni, I., K. Hlioui, and F. Zehri. (2012). Audit quality and earnings management in the Tunisian context. Journal of Accounting and Financial Reporting, 2 (2): 17-33.

Zhong, K., Gribbin, D.G., and Zheng, X. (2007). The Effect of Monitoring by Outside Blockholders on Earnings Management. Quarterly Journal of Business and Economics 46 (1) 37-58. 